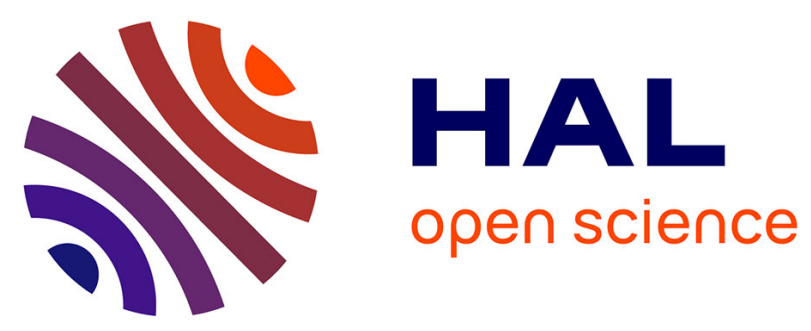

\title{
First evidence of laccase activity in the Pacific oyster Crassostrea gigas
}

\author{
Andrea Luna Acosta, Eric Rosenfeld, Myriam Amari, Ingrid \\ Fruitier-Arnaudin, Paco Bustamante, Hélène Thomas-Guyon
}

\section{- To cite this version:}

Andrea Luna Acosta, Eric Rosenfeld, Myriam Amari, Ingrid Fruitier-Arnaudin, Paco Bustamante, et al.. First evidence of laccase activity in the Pacific oyster Crassostrea gigas. Fish and Shellfish Immunology, 2010, 28 (4), pp.719-726. 10.1016/j.fsi.2010.01.008 . hal-00477727v2

\section{HAL Id: hal-00477727 \\ https://hal.science/hal-00477727v2}

Submitted on 3 May 2010

HAL is a multi-disciplinary open access archive for the deposit and dissemination of scientific research documents, whether they are published or not. The documents may come from teaching and research institutions in France or abroad, or from public or private research centers.
L'archive ouverte pluridisciplinaire HAL, est destinée au dépôt et à la diffusion de documents scientifiques de niveau recherche, publiés ou non, émanant des établissements d'enseignement et de recherche français ou étrangers, des laboratoires publics ou privés. 
2

3 Andrea Luna-Acosta, Eric Rosenfeld, Myriam Amari, Ingrid Fruitier-Arnaudin, Paco

4 Bustamante, Hélène Thomas-Guyon

5

6

7

8 Littoral Environnement et Sociétés (LIENSs), UMR 6250, CNRS-Université de La Rochelle,

92 rue Olympe de Gouges, F-17042 La Rochelle Cedex 01, France

10

11

12

13

* Corresponding authors: H. Thomas-Guyon and A. Luna-Acosta

14

Littoral Environnement et Sociétés (LIENSs),

15

UMR 6250, CNRS-Université de La Rochelle,

16

2 rue Olympe de Gouges

17

F-17042 La Rochelle Cedex 01, France

18

Email : hthomas@univ-lr.fr / aluna1508@yahoo.com

19

Tel : +33(0)5 46507623

20

Fax : +33(0)5 46507663

21 
Abstract: Phenoloxidases (POs) are a family of enzymes including tyrosinases, catecholases and laccases, which play an important role in immune defence mechanisms in various invertebrates. The aim of this study was to thoroughly identify the PO-like activity present in the hemolymph of the Pacific oyster Crassostrea gigas, by using different substrates (i.e. dopamine and $p$-phenylenediamine, PPD) and different PO inhibitors. In order to go deeper in this analysis, we considered separately plasma and hemocyte lysate supernatant (HLS). In crude plasma, oxygraphic assays confirmed the presence of true oxidase activities. Moreover, the involvement of peroxidase(s) was excluded. In contrast to other molluscs, no tyrosinaselike activity was detected. With dopamine as substrate, PO-like activity was inhibited by the PO inhibitors tropolone, phenylthiourea (PTU), salicylhydroxamic acid and diethyldithiocarbamic acid, by a specific inhibitor of tyrosinases and catecholases, i.e. 4-hexylresorcinol (4-HR), and by a specific inhibitor of laccases, i.e. cetyltrimethylammonium bromide (CTAB). With PPD as substrate, PO-like activity was inhibited by PTU and CTAB. In precipitated protein fractions from plasma, and with dopamine and PPD as substrates, PTU and 4-HR, and PTU and CTAB inhibited PO-like activity, respectively. In precipitated protein fractions from hemocyte lysate supernatant, PTU and CTAB inhibited PO-like activity, independently of the substrate. Taken together, these results suggest the presence of both catecholase- and laccase-like activities in plasma, and the presence of a laccase-like activity in HLS. To the best of our knowledge, this is the first time that a laccase-like activity is identified in a mollusc by using specific substrates and inhibitors for laccase, opening new perspectives for studying the implication of this enzyme in immune defence mechanisms of molluscs of high economic value such as $C$. gigas.

Key Words: phenoloxidase; catecholase; melanin; mollusc; bivalve; hemolymph; hemocyte; plasma 


\section{Introduction}

Phenoloxidases are a family of copper proteins, widely distributed in microorganisms, plants and animals $[1,2]$. They are the rate limiting enzymes in enzymatic browning in fruits and vegetables, and in melanization in animals. Melanin production starts with the oxidation of phenols and the concomitant reduction of $\mathrm{O}_{2}$ to water. This reaction is catalysed by POs and yields to corresponding quinones, which are then polymerized by non-enzymatic reactions toward the formation of melanin [3]. Melanin and intermediates are toxic substances with fungistatic, bacteriostatic and antiviral properties [4]. In invertebrates, PO enzymes are also involved in many cellular defence responses, such as self/non-self recognition, phagocytosis and nodule and capsule formation [4, 5]. Interestingly, similarities of the PO system have been drawn with other cascades involved in defence such as the Drosophila-Toll cascade and the mammalian complement and blood clotting [6].

A major constraint when studying POs is the ambiguity of nomenclature existing in the literature. POs include tyrosinases (monophenol, o-diphenol: $\mathrm{O}_{2}$ oxidoreductase, EC 1.14.18.1), catecholases (o-diphenol: $\mathrm{O}_{2}$ oxidoreductase, EC 1.10.3.1), and laccases ( $p$ diphenol: $\mathrm{O}_{2}$ oxidoreductase, benzenediol: $\mathrm{O}_{2}$ oxidoreductase, EC 1.10.3.2). However, tyrosinases and POs, and tyrosinases and catecholases have been used in the literature as synonyms [7, 8], and tyrosinases and POs are given the same EC number even if they are not obviously the same. POs are capable of $o$-diphenol oxidation. However, among these three enzymes, only tyrosinases can hydroxylize monophenols (e.g. L-tyrosine) and only laccases can oxidise $p$-diphenols and aromatic amines (e.g. $p$-phenylenediamine) $[9,10]$. In addition to that, various compounds have been described as inhibitors of these three types of POs with their respective specificity (Table 1). 
71 POs have been detected in different bivalve species, such as mussels (Mytillus edulis, Mytillus 72 galloprovincialis, Perna viridis), clams (Ruditapes decussatus), scallops (Nodipecten subnodosus) and oysters (Crassostrea gigas Crassotrea virginica, Saccostrea glomerata) [1117]. Among bivalves, the Pacific oyster C. gigas (Thunberg, 1753) is an ecologically and economically important species that dominates over all other molluscs with respect to global world distribution and aquaculture production [18]. However, massive summer mortalities in C. gigas have become a widespread concern in the world in recent decades [19]. Among the different factors suspected to be responsible of these mortalities, impairment of immune defence functions, elicited by environmental factors, is considered to be of major importance [20]. The increasing interest for PO comes from its apparent role in immune defence mechanisms in oysters, e.g. in the resistance of S. glomerata to Marteilia sydneyi [17]. Moreover, ecotoxicological studies have shown that PO in $C$. gigas may be modulated by the presence of heavy metals or polyaromatic hydrocarbons [21, 22]. To the best of our knowledge, studies on PO in C. gigas have been carried out by using the non specific $o$ diphenol substrate L-3,4-dihydroxyphenylalanine (L-DOPA).

In this general context, the purpose of our work was to thoroughly identify the PO-like activity that has been previously detected in $C$. gigas. We compared PO activity in plasma from $C$. gigas in the presence of several tyrosinase, catecholase and laccase substrates and inhibitors. Furthermore, we measured oxygen uptakes during enzymatic and non-enzymatic oxidation reactions. Finally, partial purification of proteins from plasma and hemocyte lysate supernatant was used to identify PO-like activities in the hemolymph. 
93

94

95

96

97

98

99

100

101

102

103

104

105

106

107

108

109

110

111

112

113

114

115

116

\section{Materials and methods}

\subsection{Oysters} arrival in the laboratory.

\subsection{Collection of plasma} at $-80^{\circ} \mathrm{C}$. Each aliquot was used only once.

\subsection{Hemocyte lysate supernatant} studies. Aliquots $(100 \mu \mathrm{l})$ were stored at $-80^{\circ} \mathrm{C}$. Each aliquot was used only once.

One hundred 3 years old $C$. gigas (mean $\pm \mathrm{SD}$; weight: $75.5 \pm 8.7 \mathrm{~g}$; length: $9 \pm 3 \mathrm{~cm}$ ) were purchased during October-November 2008 from shellfish farms in Aytré Bay (Charente Maritime, France), on the French Atlantic coast, and were processed immediately after their

After opening the oyster shells by cutting off the adductor muscle, a quantity $(0.5-1 \mathrm{ml})$ of hemolymph was withdrawn directly from the pericardial cavity with a 1-ml syringe equipped with a needle $(0.9 \times 25 \mathrm{~mm})$, and the hemolymph from 10 oysters was pooled to reduce interindividual variation [21]. Hemolymph samples were centrifuged $\left(260 \mathrm{~g}, 10 \mathrm{~min}, 4^{\circ} \mathrm{C}\right)$ to separate the cellular fraction (i.e. hemocytes) from plasma [23]. Aliquots (100 $\mu$ l) were stored

Hemocytes were homogenized at $4{ }^{\circ} \mathrm{C}$ in Tris buffer $(0.1 \mathrm{M}$ Tris $\mathrm{HCl}, 0.45 \mathrm{M} \mathrm{NaCl}, 26 \mathrm{mM}$ $\mathrm{MgCl}_{2}$ and $10 \mathrm{mM} \mathrm{CaCl}$ ) adjusted to $\mathrm{pH}$ 7. They were lysed using an Ultra-Turrax (T25 basic, IKA-WERKE) at $19000 \mathrm{rpm}$ for $30 \mathrm{sec}$ and a Thomas-Potter homogenizer (IKALabortechnik, clearance $0.13-0.18 \mathrm{~mm}$ ) at $200 \mathrm{rpm}$ for $1 \mathrm{~min}$, and centrifuged at $10000 \mathrm{x}$ g for $10 \mathrm{~min}$ at $4^{\circ} \mathrm{C}$. The resulting hemocyte lysate supernatant (HLS) was collected for enzymatic 
119 L-tyrosine, p-hydroxyphenyl propionic acid (PHPPA), 4-hydroxyanisole (4-HA), L-3,4-

120 dihydroxyphenylalanine (L-DOPA), 3,4-dihydroxyphenyl propionic acid (DHPPA), catechol, 121 dopamine, p-phenylenediamine (PPD), 4-Hydroxy-3,5-dimethoxybenzaldehyde azine 122 (syringaldazine), 2,2'-Azino-bis(3-ethylbenzothiazoline-6-sulfonic acid) diammonium salt 123 (ABTS), tropolone, 4-hexylresorcinol (4-HR), cethyltrimethylammonium bromide (CTAB), 124 salicylhydroxamic acid (SHAM), sodium azide $\left(\mathrm{NaN}_{3}\right)$, diethyldithiocarbamate (DETC), 1125 phenyl-2-thiourea (PTU), trizma hydrochloride (Tris $\mathrm{HCl}$ ), sodium chloride ( $\mathrm{NaCl}$ ), 126 ammonium sulphate $\left(\left(\mathrm{NH}_{4}\right)_{2} \mathrm{SO}_{4}\right)$ and catalase from bovine liver were obtained from Sigma127 Aldrich (France). 2-mercaptoethanol (2-ME) was obtained from MERCK (France). 128 Magnesium chloride $\left(\mathrm{MgCl}_{2}\right)$ and calcium chloride $\left(\mathrm{CaCl}_{2}\right)$ were obtained from Acros 129 (France).

\subsection{Phenoloxidase assays}

132 Phenoloxidase-like (PO-like) activity has been reported to be higher in plasma than in HLS

133 from C. gigas [23]. Therefore, constitutive PO-like activity was first analyzed in crude

134 plasma. PO-like activity was measured spectrophotometrically by recording the formation of 135 o-quinones. The method of Asokan et al. [5] was used with some modifications. Working 136 solutions of substrates were prepared just before use in Tris buffer $(0.1 \mathrm{M}$ Tris $\mathrm{HCl}, 0.45 \mathrm{M}$ $137 \mathrm{NaCl}, 26 \mathrm{mM} \mathrm{MgCl} 2$ and $10 \mathrm{mM} \mathrm{CaCl}_{2}$ ) adjusted to $\mathrm{pH}$ 7, except for PPD which was 138 prepared in methanol. The latter did not affect PO-like activities in the conditions tested (data 139 not shown). Samples were distributed in 96-well microplates (Nunc, France). Ten microliters 140 of sample were incubated with $80 \mu \mathrm{l}$ of substrate and $50 \mu \mathrm{l}$ of Tris buffer at $25^{\circ} \mathrm{C}$. Several 141 control wells were systematically used: 'buffer control' containing only buffer, 'sample

142 control' containing only sample and buffer, and 'non-enzymatic control' containing only 
143 substrate and buffer. Immediately after substrate addition, PO-like activity was monitored

144 during $4 \mathrm{~h}$ by following the increase of absorbance at a specific wavelength (Table 2).

145 Because of solubility constraints, in the case of PPD, the protocol was slightly modified: $10 \mu 1$

146 of sample were incubated with $7 \mu \mathrm{l}$ of PPD and $123 \mu \mathrm{l}$ of buffer and PO-like activity was

147 monitored during $2 \mathrm{~h}$. For all conditions, experiments were performed with three oyster pools.

148 Each pool was tested in triplicate wells and average rates were calculated. For non-enzymatic

149 oxidation, results were expressed as the mean value of the increment of absorbance per

150 minute $\left(\Delta \mathrm{A} \min ^{-1}\right)$. For enzymatic oxidation, results were systematically corrected for non-

151 enzymatic autoxidation of the substrate. Specific activities (SA) were expressed in

152 international units (IU) per $\mathrm{mg}$ of total protein. One IU is defined as the amount of enzyme

153 that catalyzes the appearance of $1 \mu$ mole of product per min [24].

154 Apparent Michaelis-Menten constants $\left(K m_{\text {app }}\right)$ and maximum velocities $\left(V m_{\text {app }}\right)$ were 155 estimated from double reciprocal plots (Lineweaver-Burk) of velocity vs substrate 156 concentration.

\subsection{Phenoloxidase inhibition assay}

159 PO inhibition assay was performed by preincubating $10 \mu \mathrm{l}$ of PO inhibitor (prepared at 160 various concentrations in Tris buffer, Fig. 3) with $10 \mu \mathrm{l}$ of sample for $20 \mathrm{~min}$, at $25^{\circ} \mathrm{C}$. Then, 161 PO assay was carried out with dopamine or PPD, at final concentrations of $100 \mathrm{mM}$ and 50 $162 \mathrm{mM}$, respectively. Experiments were performed with three oyster pools. Each pool was tested 163 in triplicate wells and average rates were calculated. Enzymatic oxidation (in the presence of

164 PO inhibitor) was systematically corrected for non-enzymatic autoxidation of the substrate (in 165 the presence of PO inhibitor). 


\subsection{Hydrogen peroxide scavenging by exogenous catalase}

Plasma $(10 \mu \mathrm{l})$ was preincubated at $25^{\circ} \mathrm{C}$ for 30 minutes in the presence of $10 \mu \mathrm{l}$ of catalase from bovine liver at $1000 \mathrm{U} / \mathrm{ml}$ [25]. The total scavenging of $\mathrm{H}_{2} \mathrm{O}_{2}$ was verified using the

Catalase kit CAT-100 (Sigma) and specifications included (data not shown). Then, PO assay was carried out with dopamine $(100 \mathrm{mM})$ or PPD $(50 \mathrm{mM})$. The effect of catalase on nonenzymatic autoxidation was also followed by incubating $\left(25^{\circ} \mathrm{C}, 30 \mathrm{~min}\right)$ the substrates (dopamine or PPD at $100 \mathrm{mM}$ or $50 \mathrm{mM}$, respectively) in the presence of $10 \mu \mathrm{l}$ of catalase. Enzymatic oxidation (in the presence of catalase) was systematically corrected for autoxidation of the substrate (in the presence of catalase). All the experiments were performed with three oyster pools. Each pool was tested in triplicate wells and average rates were calculated.

\subsection{Protein determination}

Protein concentration was determined by the slightly modified Lowry method, as described previously [26]. Serum albumin (Sigma-Aldrich, France) was used as standard.

\subsection{Measurements of oxygen uptake}

Oxygen uptake was followed with a Clark-type oxygen electrode (Hansatech, DW1) in a $700-\mu 1$ closed chamber thermostatted at $25^{\circ} \mathrm{C}$ with continuous stirring [27]. In a typical experiment, oxygen uptakes were recorded simultaneously using four separate electrode units. In the first unit ('buffer control'), a volume of $700 \mu 1$ of buffer was distributed in the chamber. In the second unit ('sample control'), $250 \mu 1$ of plasma and $450 \mu 1$ of buffer were distributed. In the third unit ('non-enzymatic control'), $700 \mu$ of substrate (L-DOPA $10 \mathrm{mM}$ or dopamine $100 \mathrm{mM}$ ) were distributed. In the fourth unit, $250 \mu \mathrm{l}$ of plasma and $450 \mu 1$ of substrate were distributed. With PPD $(50 \mathrm{mM})$ as substrate, the same protocol was adopted with slight 
193

194

195

196

197

modifications, i.e. $500 \mu \mathrm{l}$ of the sample were incubated with $35 \mu 1$ of PPD and $165 \mu 1$ of buffer. All the experiments were carried out with three oyster pools.

\subsection{Preparation of protein fractions from plasma and hemocyte lysate supernatant}

Plasma and HLS were precipitated overnight with $60 \%$ saturated $\left(\mathrm{NH}_{4}\right)_{2} \mathrm{SO}_{4}$ solution at $4{ }^{\circ} \mathrm{C}$. After centrifugation at $10000 \mathrm{xg}$ for $10 \mathrm{~min}$ at $4^{\circ} \mathrm{C}$, the precipitate was dissolved in $1 \mathrm{ml}$ and dialyzed against Tris buffer. Partially purified fractions from plasma and hemocyte lysate supernatant were filtered through a $0.22-\mu \mathrm{m}$ sterile filter (Millipore membrane-Millipore Co., Bedford, MA, USA), in order to eliminate the natural bacterial flora of samples. In order to make certain the absence of bacteria after this treatment, the samples were incubated with 4.0 $\mathrm{ml}$ of Zobell medium (4 g peptone, $1 \mathrm{~g}$ yeast extract, $0.1 \mathrm{~g}$ ferric phosphate, $30 \mathrm{~g}$ sea salt per liter) and grown at $25^{\circ} \mathrm{C}$ with shaking to allow potential bacterial growth. Then, $\mathrm{A}_{620 \mathrm{~nm}}$ readings were carried out at 0,5 and $6 \mathrm{~h}$, which evidenced the absence of bacterial growth (data not shown). Aliquots $(100 \mu \mathrm{l})$ of the dialyzates were stored at $-80^{\circ} \mathrm{C}$ before being tested for PO-like activity.

\subsection{Statistical analysis}

All values are reported as mean \pm standard deviation (SD). Statistical analysis was carried out with SYSTAT 11.0. Values were tested for normality (Shapiro test) and homogeneity of variances (Bartlett test). For normal values, an ANOVA test was used to analyse the results, followed by a Dunnett post-hoc test. For non normal values, a Kruskal-Wallis test was used, followed by a Dunn's multiple comparisons test [28]. Statistical significance was designed as being at the level of $p<0.05, p<0.01$ or $p<0.001$. 


\section{Results}

\subsection{Substrate specificity of PO-like activity in plasma}

221 Enzymatic oxidation results were systematically corrected for non-enzymatic autoxidation. Table 2 shows that no PO-like activity was detected in the presence of PHPPA, L-tyrosine, 4HA, DHPPA, syringaldazine and ABTS. Conversely, PO-like activity was detected using LDOPA, dopamine and PPD, with final concentrations of substrate saturation being equal to 10 $\mathrm{mM}, 100 \mathrm{mM}$ and $50 \mathrm{mM}$, respectively. $K m_{\text {app }}$ values for L-DOPA, dopamine and PPD were $K m_{\text {app }}$ for dopamine and PPD. $V m_{\text {app }}$ values for L-DOPA, dopamine and PPD were $0.45,0.51$ and $0.59 \Delta$ A. $\min ^{-1} \cdot 10^{-3}$, respectively (Table 2). Thus, $V m_{\text {app }}$ value obtained with PPD was 1.15 to 1.31 times higher than values obtained with L-DOPA and dopamine.

\section{2. $\mathrm{O}_{2}$ requirements of $\mathrm{PO}$-like activity}

232 Using oxygraphy, we easily confirmed the non-enzymatic autoxidation of L-DOPA, 233 dopamine, and to a lesser extent, of PPD (Fig. 1). Most importantly, we found that $\mathrm{O}_{2}$ uptake 234 was higher in the presence of plasma, independently of the substrate, confirming the presence of at least one PO-type oxidase in plasma.

\subsection{Effect of catalase}

238 Exogenous catalase was used to scavenge the $\mathrm{H}_{2} \mathrm{O}_{2}$ potentially involved in peroxidase239 dependent oxidation reactions. Fig. 2a shows that catalase did not affect autoxidations of 240 dopamine and PPD. Most importantly, catalase did not inhibit oxidations of both substrates in 241 the presence of plasma (Fig. 2b). Fig. $2 b$ also shows that catalase induced a two-fold increase 242 of PO-like activity with dopamine as substrate. 


\subsection{Effect of various $P O$ inhibitors}

The next step in the identification of PO-like activity in plasma from $C$. gigas consisted on studying the effect of different PO inhibitors with dopamine and PPD as substrates.

Results with dopamine are summarized in Fig. 3. Since many inhibitors are reducing agents, we systematically examined the effects of PO inhibitors on the non-enzymatic autoxidation. Autoxidation was reduced by using $\mathrm{NaN}_{3}$ at 0.1 and $1 \mathrm{mM}$, and suppressed with 2-ME and DETC at $5 \mathrm{mM}$ (Fig. 3a). These compounds were therefore not used at these concentrations for further studies. Moreover, enzymatic oxidation (in the presence of plasma and PO inhibitors) was systematically corrected for non-enzymatic autoxidation of the substrate (in the presence of PO inhibitors). Fig. 3b shows that enzymatic oxidation was strongly inhibited by $0.5 \mathrm{mM}$ DETC and $5 \mathrm{mM}$ PTU (94 and $77 \%$ inhibition, respectively), and also significantly inhibited by $8 \mathrm{mM}$ tropolone, $1 \mathrm{mM}$ SHAM, and $1 \mathrm{mM}$ CTAB $(56,33$, and 21\% inhibition, respectively). The catecholase inhibitor 4-HR (1 mM) exerted $34 \%$ inhibition.

Results with PPD as substrate are summarized in Fig. 4. Autoxidation was suppressed by DETC (0.5 mM, Fig. 4a). Therefore, DETC was not used for further studies. Tropolone (8 $\mathrm{mM})$ and the laccase inhibitor CTAB $(1 \mathrm{mM})$ only slightly interfered (stimulation) with the autoxidation of PPD. Since CTAB is the better documented inhibitor of laccase, we decided to maintain it in the study. Interestingly, Fig. $4 \mathrm{~b}$ shows that enzymatic oxidation was strongly inhibited by CTAB (1 mM). Moreover, the PO inhibitor PTU $(0.5$ and $5 \mathrm{mM})$ exerted $100 \%$ inhibition. Taken together, these results confirm the presence of a PO-like activity in C. gigas and suggest the presence of a catecholase-like and/or a laccase-like activity in plasma.

\subsection{PO-like activity in protein fractions}

Independently of the substrate, specific PO-like activity was considerably higher in hemocyte lysate supernatant (HLS) than in plasma (Fig. 5). Moreover, the results obtained with 
precipitated protein fractions confirm that the activities measured derived from a protein

269 source. Results with precipitated protein fractions from plasma are summarized in Fig. 5a,c.

270 With dopamine as substrate (Fig. 5a), the PO inhibitor PTU (5 mM) and the catecholase

271 inhibitor 4-HR (1 mM), inhibited PO-like activity by 57 and $26 \%$, respectively. In contrast to

272 the results obtained with crude plasma, the laccase inhibitor CTAB (1 mM) did not exert

273 inhibition in precipitated protein fractions from plasma. With PPD as substrate (Fig. 5c), PTU

274 and CTAB exerted 100\% inhibition of PO-like activity.

275 Results with precipitated protein fractions from HLS are summarized in Fig. 5b,d. With

276 dopamine as substrate (Fig. 5b), PTU and CTAB inhibited PO-like activity by 57 and 100\%, 277 respectively. Interestingly, with PPD as substrate (Fig. 5d), PTU and CTAB exerted 90 and $278100 \%$ inhibition, respectively.

\section{Discussion}

Most studies on PO from $C$. gigas have been performed with L-DOPA. However, this common substrate for the three classes of POs, i.e. tyrosinases, catecholases and laccases, was not appropriate to discriminate between these three classes of POs. Therefore, in the present work, various concentrations of different substrates were used for identifying the endogenous PO-like activity in hemolymph from this bivalve.

Oxidation catalyzed by POs requires $\mathrm{O}_{2}$. However, PO substrates are also readily autoxidized 288 in contact with air $[15,29]$. Therefore, a special attention should be paid to substrate 289 autoxidations before studying PO activity. Using both spectrophotometry and oxygraphy, we 290 confirmed that L-DOPA, dopamine, and to a lesser extent PPD, could be readily autoxidized. 291 These non-enzymatic oxidation reactions probably involve quinone redox cycling leading to 
292 the formation of different types and quantities of oxygen radicals and quinone-derived 293 products [30].

294 Another constraint for studying PO is the possible interference between PO inhibitors and 295 non-enzymatic autoxidation. For instance, the PO inhibitor 2-ME is also a well-known 296 reducing agent (Table 1), that may react with the substrate and/or the quinone intermediates 297 derived from the autoxidation reaction. We systematically examined the effects of various PO 298 inhibitors on substrate autoxidations. We found that 2-ME $(5 \mathrm{mM}), \mathrm{NaN}_{3}(0.1-1 \mathrm{mM})$ and 299 DETC (5 mM) interfered with dopamine autoxidation, and that DETC $(0.5 \mathrm{mM})$ interfered 300 with PPD autoxidation. 2-ME probably acts as a reducing agent while $\mathrm{NaN}_{3}$ and DETC might 301 possibly act as direct free radical scavengers [31, 32]. These inhibitors (at the concentrations 302 used) should therefore be avoided for identifying PO activity.

303 We focused on PO-like activity from crude plasma. By using both spectrophotometry and 304 oxygraphy, PO-like activity was detected in the presence of $o$-diphenols (L-DOPA, 305 dopamine), suggesting the presence of a catecholase- or laccase-like activity (Table 2, Fig. 1). 306 Interestingly, the $K m_{\text {app }}$ value for L-DOPA calculated in the current study was similar to 307 values previously described in hemocytes of $S$. glomerata and C. virginica [16, 33]. 308 Importantly, results with the laccase substrate PPD suggest the presence of a laccase-like 309 activity never reported before in this organism. However, at this stage, it remains uncertain 310 whether the dopamine oxidation activity is the result of the functioning of a mixture of 311 laccase and catecholase or of a single laccase. We next attempted to clarify this issue using 312 moderate concentrations of PO inhibitors. With dopamine as substrate, PO-like activity was 313 partially inhibited by the catecholase inhibitor 4-HR and the laccase inhibitor CTAB. With 314 PPD as substrate, PO-like activity was fully inhibited by CTAB. These data suggest that both 315 catecholase and laccase are present in the plasma of $C$. gigas. 
316 Most of the PO inhibitors listed in Table 1 are copper chelators and constitute therefore 317 potential catecholase and laccase inhibitors [34-37]. Accordingly, we found that PO-like 318 activity from plasma was inhibited by PTU, DETC, and to a lesser extent, by SHAM and 319 tropolone. PTU was previously described as an inhibitor of tyrosinases and catecholases [38] 320 but also as an inhibitor of laccases [25, 39]. It contains a sulphur compound that binds copper 321 at the active site of catecholase [40]. We found that PTU strongly inhibited dopamine and 322 PPD oxidation suggesting that it can inhibit both catecholase and laccase. To the best of our 323 knowledge, the following chemical products have been reported in the literature as laccase inhibitors : $N$-hydroxyglycine [35], $\mathrm{NaN}_{3}$ [35], ammonium tetramolybdate [41], SHAM [35], kojic acid [35] and CTAB [42-44]. We did not use $N$-hydroxyglycine because, at $\mu \mathrm{M}$ concentrations, $N$-hydroxyglycine was shown to bleach solutions of substrates oxidized either 327 chemically or enzymatically by laccase [45]. For $\mathrm{NaN}_{3}$ (Fig. 2) and ammonium tetramolybdate (data not shown), an effect was observed on the autoxidation of, at least, one laccase substrate. SHAM and kojic acid are PO inhibitors but not laccase specific [37, 46]. Therefore, although CTAB is also known as a cationic detergent, it appeared to be the most 331 pertinent laccase inhibitor. Indeed, CTAB was the only molecule reported as a specific 332 inhibitor of laccase but not other phenoloxidases [42-44], and we confirmed that it did not 333 affect autoxidation of laccase substrates.

334 Several difficulties are encountered when identification of a PO-like activity is performed in a 335 non purified or in a partially purified tissue homogenate because substrates used by PO may 336 be used by (i) peroxidases (ii) hemocyanins, (iii) cytochrome oxidases (EC 1.9.3.1) and (iv) 337 ceruloplasmines or ferroxidases (EC 1.16.3.1). Oxygraphic data showed the involvement of 338 true oxidase activities in plasma (Fig. 1). The involvement of peroxidases [47] was excluded 339 since exogenous catalase did not inhibit dopamine and PPD oxidation activities. It should be 340 noted that, with dopamine as substrate, catalase induced a two-fold increase of PO-like 
341 activity. This could be explained by the generation of $\mathrm{H}_{2} \mathrm{O}_{2}$ as an auto-inhibitor of PO during

342 dopamine oxidation [48]. Hemocyanins, cytochrome oxidases, and ceruloplasmins are absent

343 in the plasma and in the HLS obtained from $C$. gigas [49-52]. Therefore, only PO-like activity

344 was detected in crude plasma.

345 In order to confirm that PO-like activity observed in crude plasma was unambiguously due to

346 a protein source, the next step was to partially purify fractions from plasma. Our data obtained

347 with precipitated protein fractions confirmed that the signal measured was from a protein

348 source (Fig. 5). The results obtained with dopamine and PPD as substrates and with PTU (5

$349 \mathrm{mM}), 4-\mathrm{HR}(1 \mathrm{mM})$ and CTAB $(1 \mathrm{mM})$ as inhibitors confirmed the presence of a catecholase-

350 like and a laccase-like activity in plasma (Fig. 5a,c). Precipitated protein fractions from HLS

351 were tested for PO-like activity with the aim to localize endogenous PO-like activity in

352 hemolymph from $C$. gigas. Independently of the substrate, specific PO-like activity was

353 considerably higher in hemocyte lysate supernatant (HLS) than in plasma (Fig. 5). In addition,

354 we found that catecholase-like activity was absent in the HLS while a high laccase-like

355 activity was detected in this fraction (Fig. 5b,c). Therefore, the type of PO-like activity that

356 can be detected depends on the hemolymphatic compartment that is studied, i.e. (i) two types

357 of PO-like activity can be detected in plasma (catecholase and laccase), and (ii) one type of

358 PO-like activity can be detected in HLS (laccase).

359 It is important to notice that, with dopamine as substrate, CTAB inhibited $21 \%$ of PO-like

360 activity in crude plasma samples, suggesting the presence of a laccase in the plasma of $C$.

361 gigas. However, this inhibitory effect was suppressed in precipitated protein fractions. Thus,

362 results with crude plasma suggest that (i) a parasitic reaction (even minor) is measured in

363 parallel with the enzymatic dopamine oxidation and that (ii) this parasitic reaction is

364 suppressed when proteins are precipitated. This confirms the interest of this purification step 365 for identification of PO-like activity. 
366 POs are an important component in immune defence mechanisms in bivalves. For example,

367 the importance of phenoloxidase activity in the resistance to $M$. sydneyi has been reported in 368 S. glomerata [17]. Besides, the presence of laccases has previously been evoked in molluscs $369[16,53]$. Moreover, a gene encoding a laccase was recently identified from Pacific oyster, $C$. 370 gigas, hemocytes (Faury and Renault, pers. comm.) and its total sequence deposited in 371 GenBank under accession $\mathrm{n}^{\mathbf{0}}$ NCBI ID: EU678320. This gene was shown to be over372 expressed in the presence of polyaromatic hydrocarbons, suggesting a potential use of laccase 373 as a biomarker of pollution exposure [54]. In this context, the present study demonstrates, for

374 the first time through the use of a panel of POs substrates and inhibitors, that a laccase-like 375 activity is present in a mollusc species, the Pacific oyster, $C$. gigas. A better characterization 376 of laccase and/or catecholase systems would help to extend our knowledge on immune 377 defence mechanisms in C. gigas, and thus, would improve our ability to monitor and manage 378 the production and survival of this important species.

380 Acknowledgments

381 This study was supported by a PhD grant from the Conseil Général of the Charente-Maritime 382 for A. Luna-Acosta. The Conseil Régional de Poitou-Charentes is acknowledged for financial 383 support through the research project 'POLERON' (Modifications chimiques de polluants 384 organiques dans le bassin de Marennes-Oléron, toxicité des produits de dégradation sur 385 l'huître creuse). 


\section{References}

387 [1] Sanchez-Ferrer A, Rodriguez-Lopez JN, Garcia-Canovas F, Garcia-Carmona F. 388 Tyrosinase: a comprehensive review of its mechanism. Biochim Biophys Acta. 1995;1247:138911.

390 [2] Chase MR, Raina K, Bruno J, Sugumaran M. Purification, characterization and molecular 391 cloning of prophenoloxidases from Sarcophaga bullata. Insect Biochem Mol Biol. 392 2000;30:953-67.

393 [3] Rodriguez-Lopez JN, Tudela J, Varon R, Garcia-Carmona F, Garcia-Canovas F. Analysis of a kinetic model for melanin biosynthesis pathway. J Biol Chem. 1992;267:3801-10.

[4] Söderhäll K, Cerenius L. Role of the prophenoloxidase-activating system in invertebrate immunity. Curr Opin Immunol. 1998;10:23-8.

[5] Asokan R, Arumugam M, Mullainadhan P. Activation of prophenoloxidase in the plasma and haemocytes of the marine mussel Perna viridis Linnaeus. Dev Comp Immunol. 1997;21:1-12.

[6] Alan R, Ezekowitz B, Hoffmann J. Innate immunity: The blossoming of innate immunity. Curr Opin Immunol. 1998;10:9-11.

[7] Claus H, Decker H. Bacterial tyrosinases. System Appl Microbiol. 2006;29:3-14.

[8] Solomon EI, Sundaram UM, Machonkin TE. Multicopper oxidases and oxygenases. Chem Rev. 1996;96:2563-606.

[9] Rescigno A, Zucca P, Flurkey A, Inlow J, Flurkey WH. Identification and discrimination between some contaminant enzyme activities in commercial preparations of mushroom tyrosinase. Enzyme Microb Technol. 2007;41:620-7. [10] Thurston CF. The structure and function of fungal laccases. Soc Gen Microbiol. 1994;140:19.

[11] Coles JA, Pipe RK. Phenoloxidase activity in the haemolymph and haemocytes of the marine mussel Mytilus edulis. Fish Shellfish Immunol. 1994;4:337-52.

[12] Carballal MJ, Lopez C, Azevedo C, Villalba A. Enzymes involved in defense functions of hemocytes of mussel Mytillus galloprovincialis. J Invertebr Pathol. 1997;70:96-105.

[13] Lopez C, Carballal MJ, Azevedo C, Villalba A. Enzyme characterisation of the circulating haemocytes of the carpet shell clam, Ruditapes decussatus (Mollusca: bivalvia). Fish Shellfish Immunol. 1997;7:595-608.

[14] Asokan R, Arumugam M, Mullainadhan P. Functional analysis of plasma prophenoloxidase system in the marine mussel Perna viridis. Comp Biochem Physiol A: Mol Integr Physiol. 1998;120:753-62. [15] Luna-Gonzalez A, Maeda-Martinez AN, Vargas-Albores F, Ascencio-Valle F, RoblesMungaray M. Phenoloxidase activity in larval and juvenile homogenates and adult plasma and haemocytes of bivalve molluscs. Fish Shellfish Immunol. 2003;15:275-82.

[16] Jordan PJ, Deaton LE. Characterization of phenoloxidase from Crassostrea virginica hemocytes and the effect of Perkinsus marinus on phenoloxidase activity in the hemolymph of Crassostrea virginica and Geukensia demissa. J Shellfish Res. 2005;24:477-82.

[17] Peters R, Raftos DA. The role of phenoloxidase suppression in QX disease outbreaks among Sydney rock oysters (Saccostrea glomerata). Aquaculture. 2003;223:29-39.

[18] FAO. Aquaculture Production: Quantities 1950-2002. Fishstat Plus; 2005.

[19] Cheney DP, MacDonald BF, Elston RA. Summer mortality of Pacific oysters Crassostrea gigas (Thunberg): Initial findings on multiple environmental stressors in Puget Sound, Washington. J Shellfish Res. 2000;19:353-9.

[20] Garnier M, Labreuche Y, Garcia C, Robert M, Nicolas JL. Evidence for the involvement of pathogenic bacteria in summer mortalities of the Pacific oyster Crassostrea gigas. Microb 
[21] Gagnaire B, Thomas-Guyon H, Renault T. In vitro effects of cadmium and mercury on Pacific oyster, Crassostrea gigas (Thunberg), haemocytes. Fish Shellfish Immunol. 2004;16:501-12.

[22] Bado-Nilles A, Gagnaire B, Thomas-Guyon H, Le Floch S, Renault T. Effects of 16 pure hydrocarbons and two oils on haemocyte and haemolymphatic parameters in the Pacific oyster, Crassostrea gigas (Thunberg). Toxicol in Vitro. 2008;22:1610-7.

[23] Hellio C, Bado-Nilles A, Gagnaire B, Renault T, Thomas-Guyon H. Demonstration of a true phenoloxidase activity and activation of a ProPO cascade in Pacific oyster, Crassostrea gigas (Thunberg) in vitro. Fish Shellfish Immunol. 2007;22:433-40.

[24] Fenoll LG, Rodriguez-Lopez JN, Garcia-Molina F, Garcia-Canovas F, Tudela J. Unification for the expression of the monophenolase and diphenolase activities of tyrosinase. IUBMB Life. 2002;54:137-41.

[25] Hattori M, Konishi H, Tamura Y, Konno K, Sogawa K. Laccase-type phenoloxidase in salivary glands and watery saliva of the green rice leafhopper, Nephotettix cincticeps. J Insect Physiol. 2005;51:1359-65.

[26] Smith PK, Krohn RI, Hermanson GT, Mallia AK, Gartner FH, Provenzano M, et al. Measurement of protein using bicinchoninic acid. Anal Biochem. 1985;150:76-85.

[27] Rosenfeld E, Duport C, Zigha A, Schmitt P. Characterisation of aerobic and anaerobic growth of the food-borne pathogen Bacillus cereus F4430/73. Can J Microbiol. 2005;51:14958.

[28] Zar JH. Biostatistical analysis. 2d ed. New Jersey, USA: Prentice Hall; 1984.

[29] Hermann TE, Kurtz MB, Champe SP. Laccase localized in hulle cells and cleistothecial primordia of Aspergillus nidulans. J Bacteriol. 1983;154:955-64.

[30] Guillen F, Martinez MJ, Muñoz C, Martinez AT. Quinone redox cycling in the ligninolytic fungus Pleurotus eryngii leading to extracellular production of superoxide anion radical. Arch Biochem Biophys. 1996;339:190-9.

[31] Sagone AL Jr, Mendelson DS, Metz EN. The effect of sodium azide on the chemiluminescence of granulocytes - evidence for the generation of multiple oxygen radicals. J Lab Clin Med. 1977;339:190-9.

[32] Liu J, Shigenaga MK, Yan LJ, Mori A, Ames BN. Antioxidant activity of diethyldithiocarbamate. Free Radical Res. 1996;24:461-72.

[33] Aladaileh S, Rodney P, Nair SV, Raftos DA. Characterization of phenoloxidase activity in Sydney rock oysters (Saccostrea glomerata). Comp Biochem Physiol B: Biochem Mol Biol. 2007;148:470-80.

[34] Ögel ZB, Yüzügüllü Y, Mete S, Bakir U, Kaptan Y, Sutay D, et al. Production, properties and application to biocatalysis of a novel extracellular alkaline phenol oxidase from the thermophilic fungus Scytalidium thermophilum. Appl Microbiol Biotechnol. 2006;71:85362.

[35] Faure D, Bouillant ML, Bally R. Comparative study of substrates and inhibitors of Azospirillum lipoferum and Pyricularia oryzae laccases. Appl Env Microbiol. 1995;61:11446.

[36] Decker H, Jaenicke E. Recent findings on phenoloxidase activity and antimicrobial activity of hemocyanins. Dev Comp Immunol. 2004;28:673-87.

[37] Perez-Gilabert M, García-Carmona F. Characterization of catecholase and cresolase activities of eggplant polyphenol oxidase. J Agr Food Chem. 2000;48:695-700.

[38] Dittmer NT, Suderman RJ, Jiang H, Zhu YC, Gorman MJ, Kramer KJ, et al. Characterization of cDNAs encoding putative laccase-like multicopper oxidases and developmental expression in the tobacco hornworm, Manduca sexta, and the malaria mosquito, Anopheles gambiae. Insect Biochem Mol Biol. 2004;34:29-41. 
[39] Arias ME, Arenas M, Rodriguez J, Soliveri J, Ball AS, Hernandez M. Kraft pulp biobleaching and mediated oxidation of a nonphenolic substrate by laccase from Streptomyces cyaneus CECT 3335. Appl Env Microbiol. 2003;69:1953-8.

[40] Gerdemann C, Eicken C, Krebs B. The crystal structure of catechol oxidase: New insight into the function of type-3 copper proteins. Acc Chem Res. 2002;35:183-91.

[41] Flurkey A, Cooksey J, Reddy A, Spoonmore K, Rescigno A, Inlow J, et al. Enzyme, protein, carbohydrate, and phenolic contaminants in commercial tyrosinase preparations: potential problems affecting tyrosinase activity and inhibition studies. J Agr Food Chem. 2008;56:4760-8.

[42] Walker JRL, McCallion RF. The selective inhibition of ortho- and para-diphenol oxidases. Phytochemistry. 1980;19:373-7.

[43] Mazzafera P, Robinson SP. Characterization of polyphenol oxidase in coffee. Phytochemistry. 2000;55:285-96.

[44] Martinez-Alvarez O, Montero P, Gomez-Guillen C. Evidence of an active laccase-like enzyme in deepwater pink shrimp (Parapenaeus longirostris). Food Chem. 2008;108:624-32.

[45] Zhang J, Kjonaas R, Flurkey WH. Does N-hydroxyglycine inhibit plant and fungal laccases? Phytochemistry. 1999;52:775-83.

[46] Zhang X, Flurkey WH. Phenoloxidases in Portabella mushrooms. J Food Sci. 1997;62:97-100.

[47] Christensen BM, Li J, Chen CC, Nappi AJ. Melanization immune responses in mosquito vectors. Trends Immunol. 2005;21:192-9.

[48] Muñoz-Muñoz JL, Garcia-Molina F, Varon R, Tudela J, Garcia-Canovas F, RodriguezLopez JN. Generation of hydrogen peroxide in the melanin biosynthesis pathway. Biochim Biophys Acta. 2009;1794:1017-29.

[49] Eble A, Kennedy VS, Newell RIE. The eastern oyster Crassostrea virginica. College Park, MD, USA: Maryland Sea Grant Book; 1996.

[50] Lannig G, Cherkasov AS, Pörtner HO, Bock C, Sokolova IM. Cadmium-dependent oxygen limitation affects temperature tolerance in eastern oysters (Crassostrea virginica Gmelin). Am J Physiol. 2008;294:1338-46.

[51] Schosinsky KH, Lehmann HP, Beeler MF. Measurement of ceruloplasmin from its oxidase activity in serum by use of o-dianisidine dihydrochloride. Clin Chem. 1974;20:155663.

[52] Kawai K. The cytochrome system in marine lamellibranch tissues. Biol Bull. 1959;117:125-32.

[53] Bedouet L, Marie A, Dubost L, Peduzzi J, Duplat D, Berland S, et al. Proteomics analysis of the nacre soluble and insoluble proteins from the oyster Pinctada margaritifera. Mar Biotechnol. 2007;9:638-49.

[54] Bado-Nilles A, Le Floch S, Renault T, Faury N, Auffret M, Quentel C, et al. Effects of two oils on immune parameters and on the expression of immune related genes in the Pacific oyster Crassostrea gigas. Physiomar; 2008.

[55] Johannes C, Majcherczyk A. Laccase activity tests and laccase inhibitors. J Biotechnol. 2000;78:193-9.

[56] Zufelato MS, Lourenço AP, Simões LP, Jorge JA, Bitondi MM. Phenoloxidase activity in Apis mellifera honey bee pupae, and ecdysteroid-dependent expression of the prophenoloxidase mRNA. Insect Biochem Mol Biol. 2004;34:1257-68.

[57] Lee JL, Kong KH, Cho SH. Purification and characterization of tyrosinase from Solanum melongena. J Biochem Mol Biol. 1997;30:150-6.

[58] Shatta A, Ei-Shamei Z. Differentiation of eggplant (Solanum melongena) polyphenoloxidase, laccase and peroxidase using selective substrates and inhibitors. Adv Food Sci. 1999;21:79-83. 
534 [59] Zavarzina AG, Zavarzin AA. Laccase and tyrosinase activities in lichens. Microbiology. 535 2006;75:546-56.

536 [60] Dawley RM, Flurkey WH. Differentiation of tyrosinase and laccase using 4537 hexylresorcinol, a tyrosinase inhibitor. Phytochemistry. 1993;33:281-4. 
540 Fig. 1 Oxygen uptake during oxidation of PO substrates. Non-enzymatic (- plasma, gray

541 lines) and enzymatic (+ plasma, black lines) oxidation reactions were followed using

542 oxygraphy with the substrates: (a) L-DOPA $10 \mathrm{mM}$, (b) dopamine $100 \mathrm{mM}$, and (c) PPD 50

$543 \mathrm{mM}$. Experiments were repeated three times for each substrate. For clarity, only one typical

544 experiment is shown. No oxygen uptake was observed in 'buffer' and 'sample' controls (data 545 not shown).

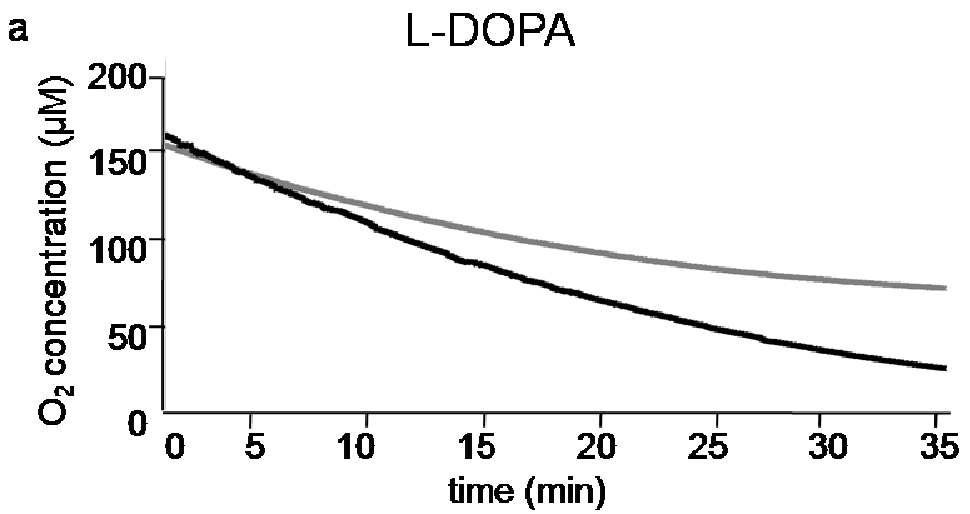

b

Dopamine
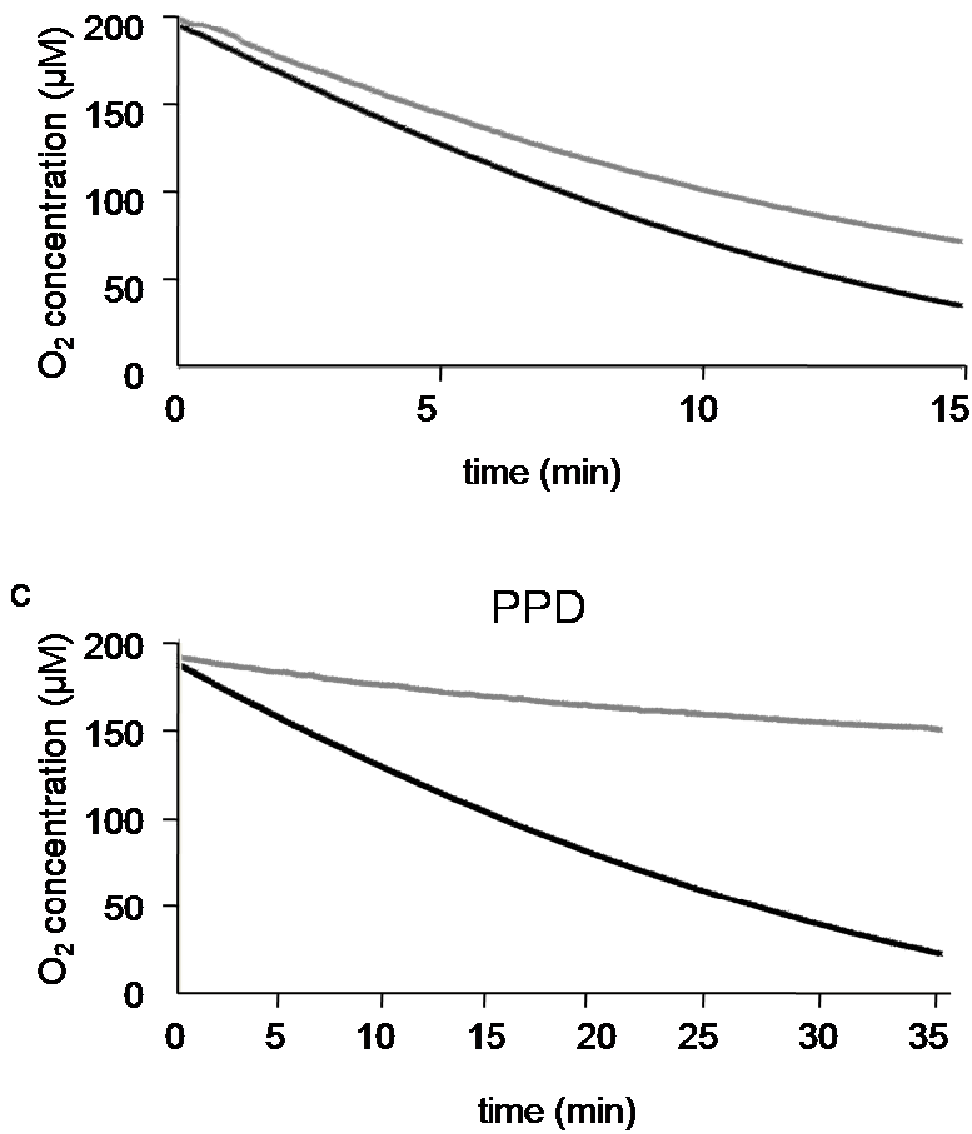
Fig. 2 Effect of catalase on autoxidation (a) and PO-like activity (b). Both dopamine and PPD

566 were used as substrates in the presence $(+$ CAT) or in the absence (- CAT) of catalase. Left y

567 axis corresponds to results obtained with dopamine +/- CAT and right y axis corresponds to

568 results obtained with PPD +/- CAT. Mean \pm SD $\mu \mathrm{mol} \min ^{-1} \operatorname{mg} \operatorname{prot}^{-1}, n=9$, *statistical 569 difference for $p<0.05$.

a Non-enzymatic autoxidation

8

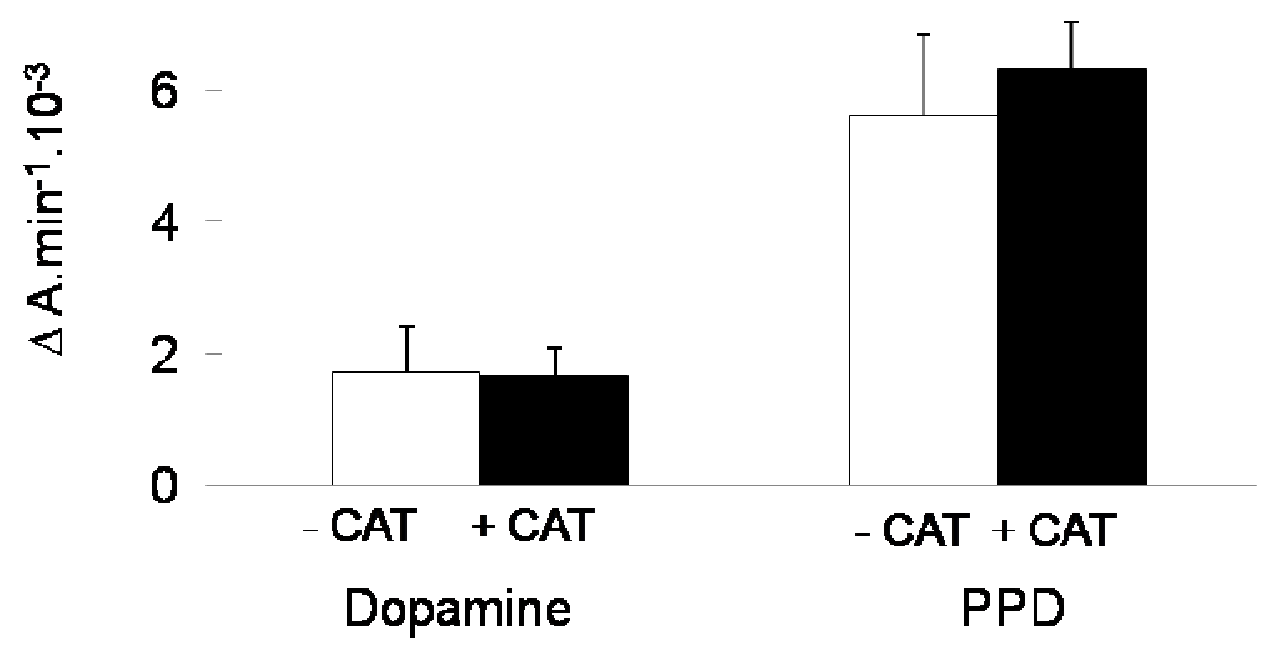

b Enzymatic oxidation

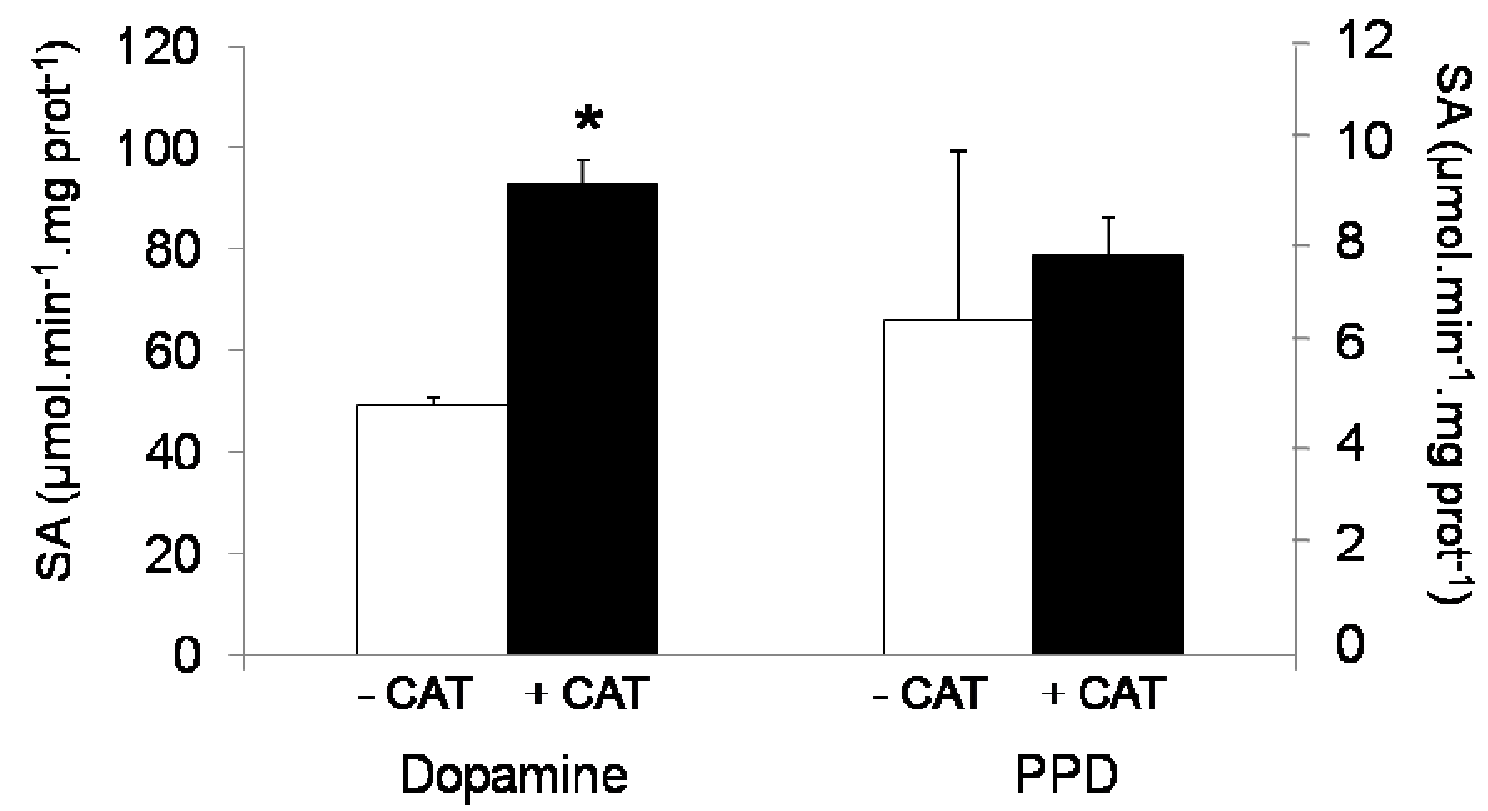


571 Fig. 3 Effect of inhibitors on autoxidation and enzymatic oxidation of dopamine. (a) Non-

572 enzymatic autoxidation (without plasma). (b) Enzymatic oxidation (with plasma). 'Control'

573 corresponds to the condition without inhibitor. PO inhibitor concentrations correspond to final

574 concentrations in the assay. Mean $\pm \mathrm{SD} \mu \mathrm{mol} \min ^{-1} \mathrm{mg} \mathrm{prot}^{-1}, n=9$, *statistical difference of $575 p<0.05, * * p<0.01$ and $* * * p<0.001$, respectively.

\section{a Non-enzymatic autoxidation of dopamine}

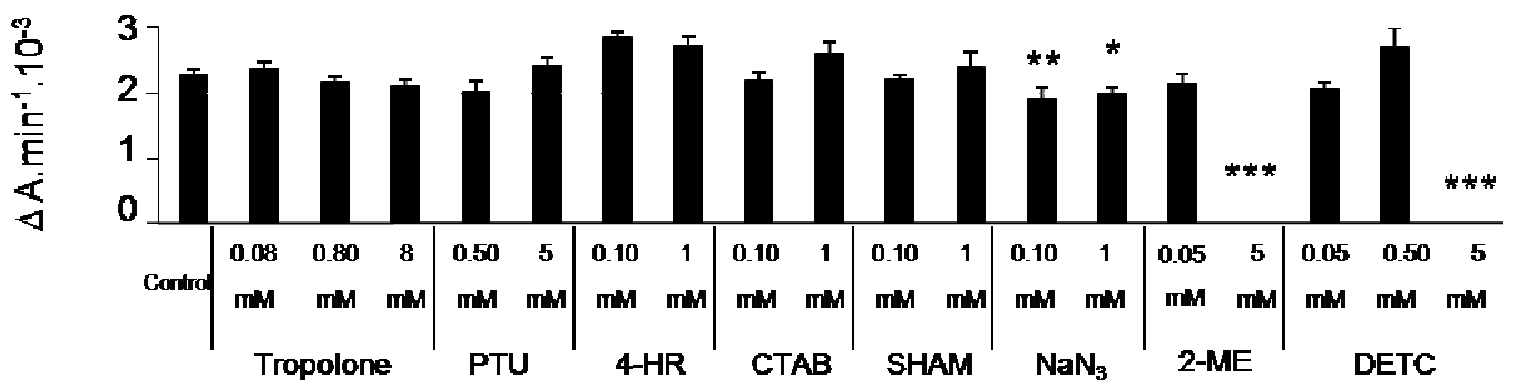

b Enzymatic oxidation of dopamine

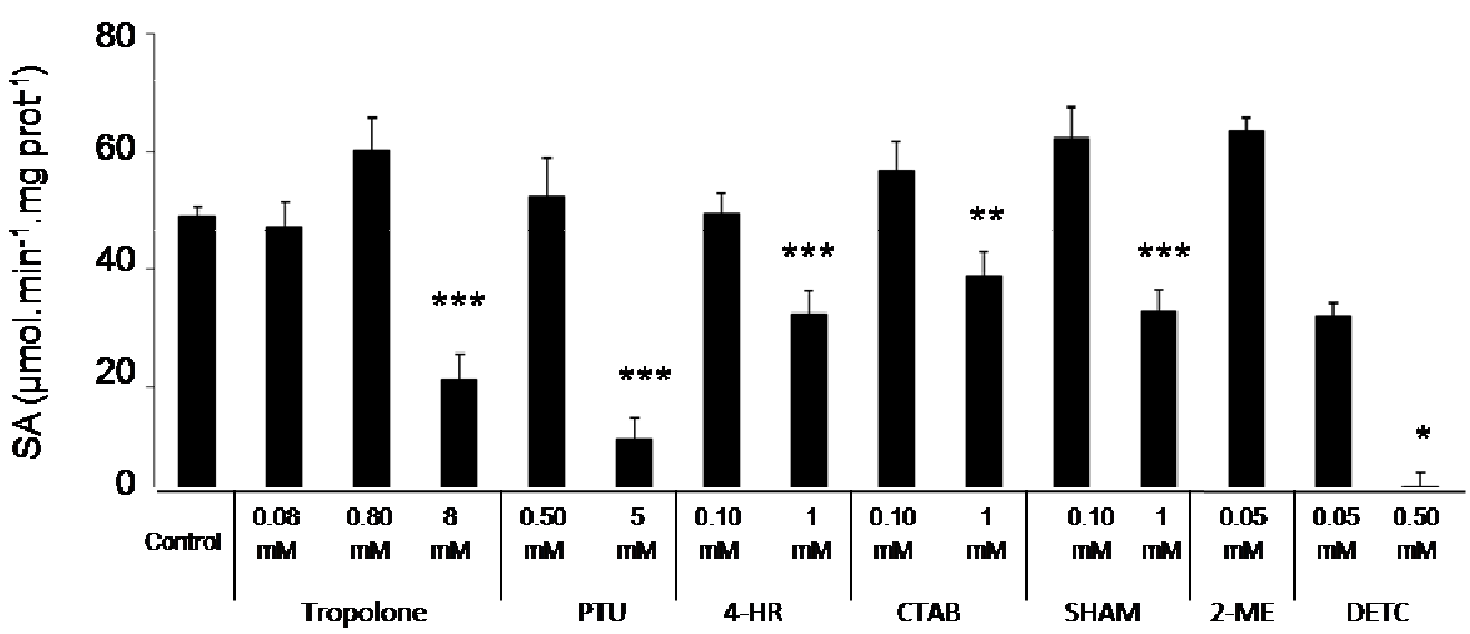


578 Fig. 4 Effect of inhibitors on autoxidation and enzymatic oxidation of PPD. (a) Non-

579 enzymatic autoxidation. (b) Enzymatic oxidation. 'Control' corresponds to the condition

580 without inhibitor. PO inhibitor concentrations correspond to final concentrations in the assay.

581 Mean \pm SD $\mu$ mol.min ${ }^{-1} \mathrm{mg} \operatorname{prot}^{-1}, n=9$, *statistical difference for $p<0.05, * * p<0.01$ and

$582 * * * p<0.001$, respectively.

a Non-enzymatic autoxidation of PPD

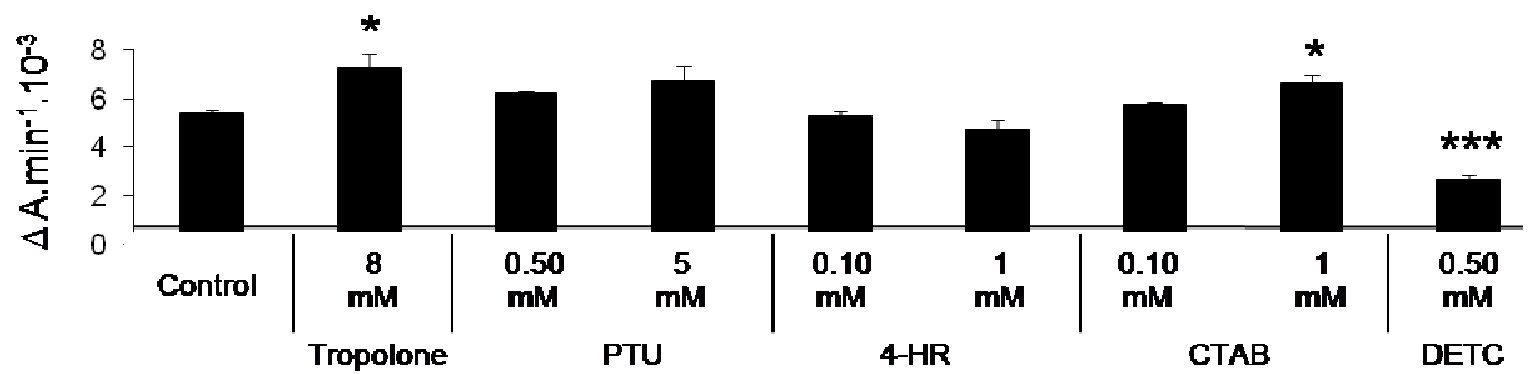

b Enzymatic oxidation of PPD

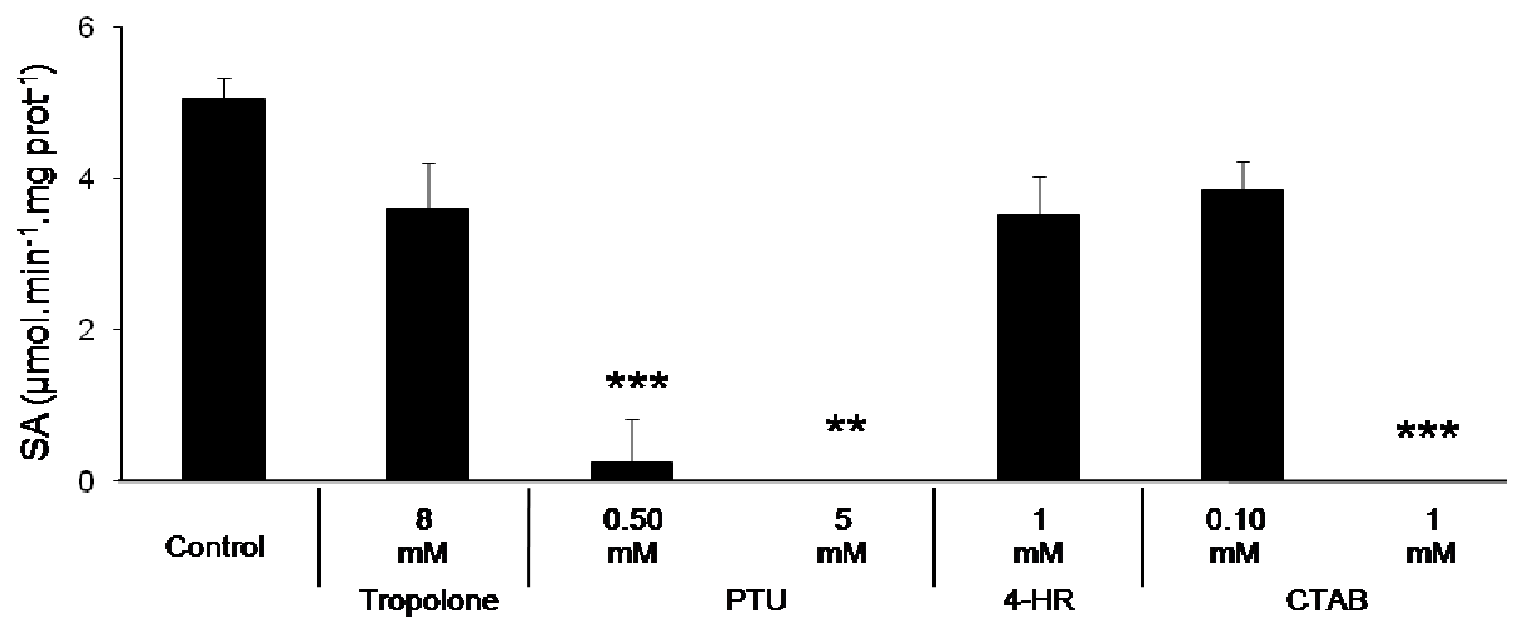


Fig. 5 Inhibition of phenoloxidase-like activity in precipitated protein fractions from plasma

586 and hemocyte lysate supernatant (HLS). Both dopamine (a, b) and PPD (c, d) were used as 587 substrates. 'Control' corresponds to the condition without inhibitor. PO inhibitor 588 concentrations correspond to final concentrations in the assay. Mean \pm SD $\mu \mathrm{mol} \mathrm{min}^{-1} \mathrm{mg}$ $589 \operatorname{prot}^{-1}, n=9$, *statistical difference for $p<0.05, * * p<0.01$ and $* * * p<0.001$, respectively.

\section{Plasma}
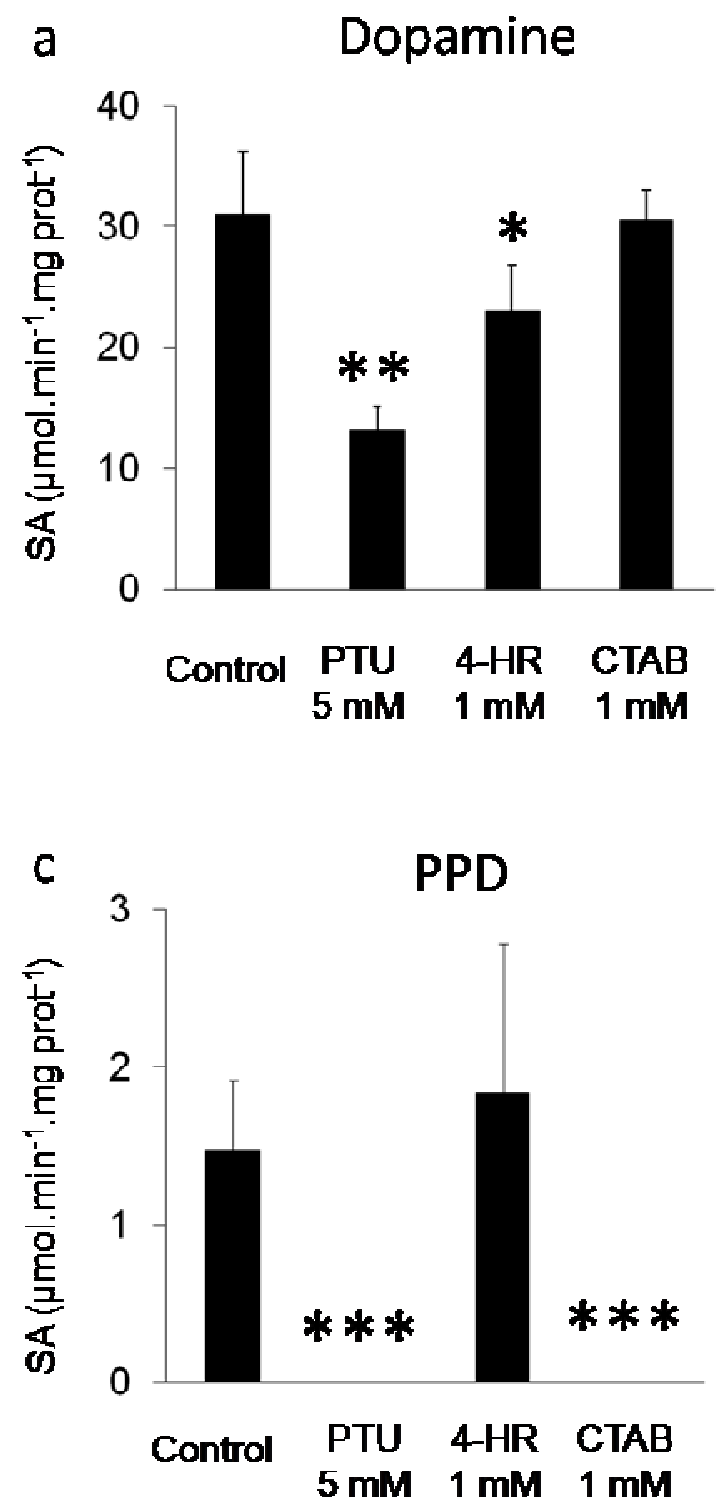
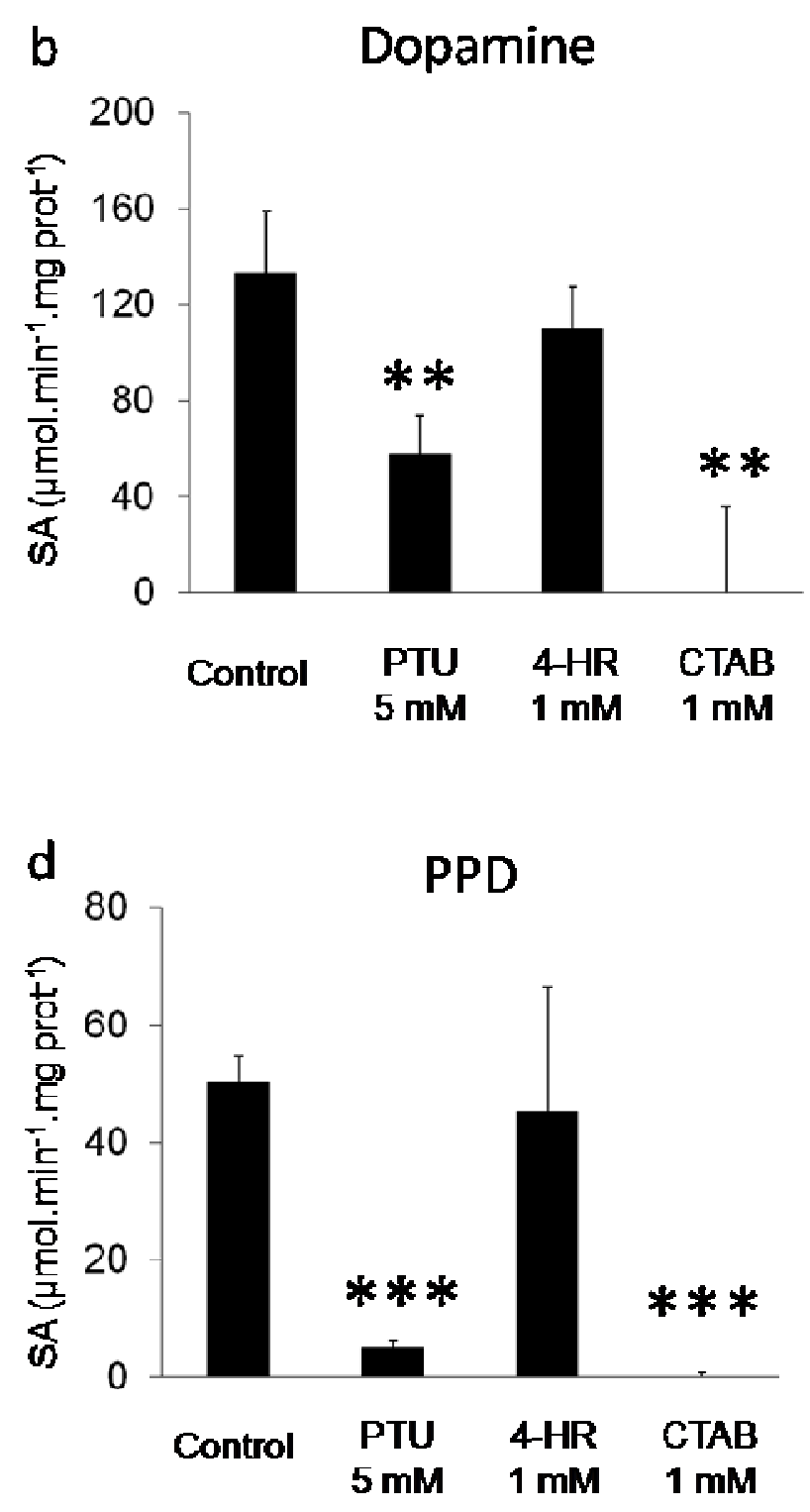

HLS 
591

592

593

594

595

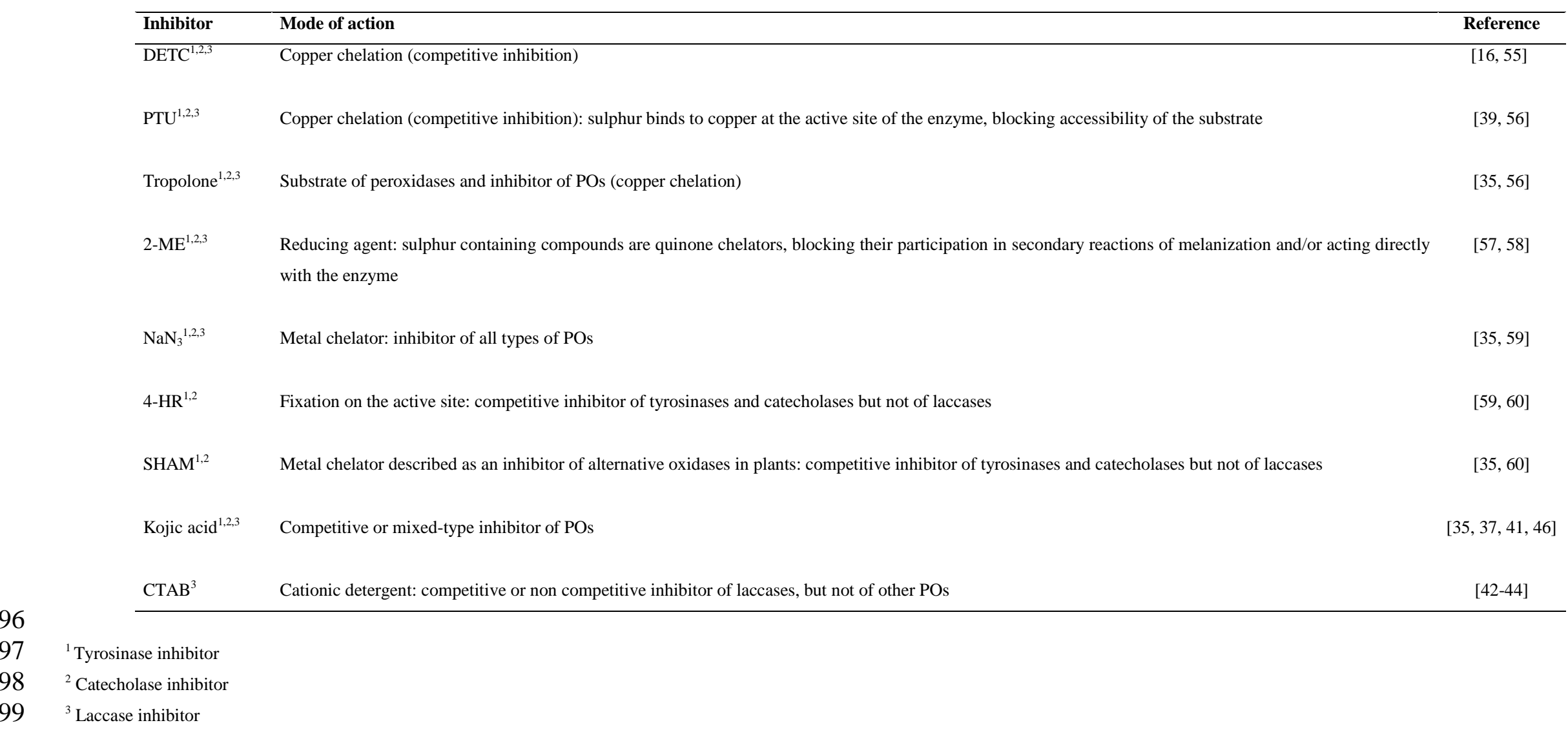

\section{Table 1}

Phenoloxidase-like inhibitors and modes of action. DETC: diethyldithiocarbamate; PTU: 1-phenyl-2-thiourea; 2-ME: 2-mercaptoethanol; NaN ${ }_{3}$ : sodium azide; 4-HR: 4Hexylresorcinol; SHAM: salicylhydroxamic acid; CTAB: cetyl trimethyl ammonium bromide. 
Table 2

601 Identification of phenoloxidase-like activity in plasma of Crassostrea gigas by using a panel of substrates. $\varnothing$, no

602 PO-like activity detected.

603

\begin{tabular}{|c|c|c|c|c|c|c|}
\hline Type of substrate & Substrate & $\lambda(\mathbf{n m})^{4}$ & $\begin{array}{l}\text { Final substrate } \\
\text { concentrations tested } \\
(\mathrm{mM})\end{array}$ & $\begin{array}{l}\text { Substrate } \\
\text { saturating } \\
\text { concentration } \\
(\mathrm{mM})\end{array}$ & $\begin{array}{l}K m_{\text {app }} \\
(\mathrm{mM})\end{array}$ & $\left(\Delta \mathrm{A} \min ^{-1} \cdot 10^{-3}\right)$ \\
\hline \multirow[t]{3}{*}{ Monophenol $^{1}$} & L-tyrosine & 490 & $4,6,8,10,20$ & $\varnothing$ & $\varnothing$ & $\varnothing$ \\
\hline & 4-HA & 490 & $4,6,8,10,20$ & $\varnothing$ & $\varnothing$ & $\varnothing$ \\
\hline & PHPPA & 490 & $4,6,8,10,20$ & $\varnothing$ & $\varnothing$ & $\varnothing$ \\
\hline \multirow[t]{3}{*}{$o$-Diphenol ${ }^{1,2,3}$} & L-DOPA & 490 & $4,6,8,10,20$ & 8 & 7 & 0.45 \\
\hline & Dopamine & 490 & $10,25,50,100,200$ & 100 & 51 & 0.51 \\
\hline & DHPPA & 400 & $4,6,8,10,20$ & $\varnothing$ & $\varnothing$ & $\varnothing$ \\
\hline Metoxi phenol ${ }^{3}$ & Syringaldazine & 525 & $0.01,0.1,1$ & $\varnothing$ & $\varnothing$ & $\varnothing$ \\
\hline \multirow[t]{2}{*}{ Non-phenolic substrates ${ }^{3}$} & ABTS & 420 & $1,2,3,4,5$ & $\varnothing$ & $\varnothing$ & $\varnothing$ \\
\hline & PPD & 420 & $5,10,25,50,100$ & 50 & 45 & 0.59 \\
\hline
\end{tabular}

604

$605{ }^{1}$ Tyrosinase substrate, in Tris buffer

$606{ }^{2}$ Catecholase substrate, in Tris buffer

$607{ }^{3}$ Laccase substrate, in methanol

$608{ }^{4}$ Wavelengths used to measure by spectrophotometry the formation of each $o$-quinone derivative 